\title{
PRE-TEST AND POST-TEST APPLICATIONS TO SHAPE THE EDUCATION OF PHLEBOTOMISTS IN A QUALITY MANAGEMENT PROGRAM: AN EXPERIENCE IN A TRAINING HOSPITAL
}

\author{
PRIMENE TESTOVA PRE I POSLE OBUKE U CILU OBLIKOVANJA EDUKACIJE FLEBOTOMISTA \\ U OKVIRU PROGRAMA UPRAVLANJA KVALITETOM: ISKUSTVO IZ BOLNICE ZA OBUKU
}

\author{
Güzin Aykal1, Mustafa Keşapli², Özgür Aydin³, Hatice Esen4, Ayşenur Yeğin1, \\ Faruk Güngör², Necat Yilmaz ${ }^{1}$ \\ ${ }^{1}$ Central Laboratories of Antalya Education and Research Hospital, Antalya, Turkey \\ 2Emergency Department of Antalya Education and Research Hospital, Antalya, Turkey \\ ${ }^{3}$ Clinical Biochemistry, Batman Maternity and Children's Hospital, Batman, Turkey \\ ${ }^{4}$ Quality Management Department of Antalya Education and Research Hospital, Antalya, Turkey
}

\begin{abstract}
Summary
Background: After the introduction of modern laboratory instruments and information systems, preanalytic phase is the new field of battle. Errors in preanalytical phase account for approximately half of total errors in clinical laboratory. The objective of this study was to share an experience of an education program that was believed to be successful in decreasing the number of rejected samples received from the Emergency Department (ED).

Methods: An education program about laboratory procedures, quality requirements in the laboratory, patient and health-care worker safety was planned by the quality team to be performed on 36 people who were responsible for sample collection in the ED. A questionary which included 11 questions about the preanalytic phase was applied to all the attendees before and after training. The number of rejected samples per million was discovered with right proportion account over the number of accepted and rejected samples to laboratory after and before the training period. Results: Most of the attendees were nurses ( $n: 22 / 55 \%)$, with over 12 years of experience in general and 2-4 years experience in the ED. Knowledge level of the attendees was calculated before training as $58.9 \%$ and after training as $91.8 \%$. While the total rate of sample rejection before training was $2.35 \%$ (sigma value $3.37-3.50$ ), the rate after training was $1.56 \%$ (sigma value $3.62-3.75$ ).
\end{abstract}

\begin{abstract}
Kratak sadržaj
Uvod: Posle uvođenja modernih laboratorijskih instrumenata i informacionih sistema, preanalitička faza postala je novo mesto okršaja. Greške u preanalitičkoj fazi čine otprilike polovinu ukupnog broja grešaka u kliničkoj laboratoriji. Cilj ove studije bio je da se podeli iskustvo sa jednim edukativnim programom za koji se veruje da doprinosi smanjenju broja odbijenih uzoraka pristiglih sa odeljenja urgentne medicine. Metode: Edukativni program o laboratorijskim procedurama, laboratorijskim zahtevima za kvalitet, bezbednosti pacijenata i zdravstvenih radnika, isplanirao je tim za kvalitet tako da se uključi 36 osoba odgovornih za prikupljanje uzoraka na odeljenju urgentne medicine. Svim učesnicima dat je pre i posle obuke upitnik sa 11 pitanja o preanalitičkoj fazi. Broj odbijenih uzoraka u milion otkriven je pomoću odgovarajuće proporcije na osnovu broja prihvaćenih i odbijenih uzoraka u laboratoriji pre i posle obuke.

Rezultati: Većinu učesnika činili su medicinski tehničari (22/55\%) sa preko 12 godina iskustva ukupno i $2-4$ godine iskustva na urgentnoj medicini. Nivo znanja kod učesnika izračunat pre obuke bio je 58,9\% a posle obuke $91,8 \%$. Dok je ukupna stopa odbijenih uzoraka pre obuke bila $2,35 \%$ (sigma vrednost $3,37-3,50$ ), ova stopa posle obuke iznosila je $1,56 \%$ (sigma vrednost $3,62-3,75$ ).
\end{abstract}

Address for correspondence:

Güzin Aykal

Antalya Eğitim ve Araştırma Hastanesi Merkez laboratuvarı Varlık Mh., Kazım Karabekir Caddesi, 07100 Antalya e-mail:guzinaykal@yahoo.com

List of abbreviations: Health care workers (HCWs), Emergency Department (ED). 
Conclusions: Increasing the knowledge of staff has a direct positive impact on the preanalytic phase. The application of a pre-test was observed to be a feasible tool to shape group specific education programs.

Keywords: knowledge management, preanalytic error, quality management

\section{Introduction}

Preanalytical errors account for $60-70 \%$ of the total errors in laboratory medicine (1). As defined, variables are mostly out of reach of the laboratory, associated with human factors, difficult to observe and to amend. However, they are as important as analytic or postanalytic errors. Reducing the error rates in all fields is the ultimate way to a well organized and productive laboratory. The best approach to get this target is to perform total quality management by evaluating the process with versatile strategies to reduce the complicated procedures and error rates by observations, to prepare best practice manuals and guidelines for health care workers ( $\mathrm{HCWs}$ ) and to evaluate their performance constantly (2).

In order to decrease or even eliminate matters which stem from weak cooperation, a sound communication is crucial between HCWs and laboratory professionals. In many cases, this solely contributes to problem-solving without any further investigations. As soon as such communication is strengthened, the following step should be a good program to handle the consequences of preanalytical errors. Education has an important role in quality processes in terms of sharing the same targets and creating standard applications (3). Educational processes and rules during this period need to be managed by laboratories and they should also be compatible with the education programs of the hospitals. Compliance to the education should be observed and precautions to increase this compliance should be followed. Moreover, effectiveness of the education should be evaluated according to the objectives and evaluations of effectiveness should also cover the performance of the trainers.

According to data from a survey of education and training on phlebotomy in 28 European countries published by the European Federation of Clinical Chemistry and Laboratory Medicine (EFLM) working group for the preanalytical phase (WG-PA), phlebotomy guidelines tend not to be followed in health care centers which are not directly controlled by laboratory personnel. They reported that education and training programs of phlebotomists who are out of laboratory control should be fortified so that sample quality and patient safety can be enhanced (4). The objective of our study was to share an experience of an education program on preanalytic phase performed on Emergency Department (ED) staff.
Zaključak: Veći nivo znanja kod osoblja ima direktan pozitivan uticaj na preanalitičku fazu. Uočeno je da primena testiranja pre obuke može biti izvodljiv način da se oblikuju edukativni programi za specifične grupe.

Ključne reči: upravljanje znanjem, preanalitička greška, upravljanje kvalitetom

\section{Materials and Methods}

In our hospital, Hospital Quality Standards procedures are followed by a laboratory quality team and preventive activities are performed when necessary. Monthly analyses for sample rejection rates are prepared by the person in charge, Root Cause Analyses are performed and results are shared with the team. When indicated, education programs are organized. In 2014, in the period November-December, error rates from the ED were strikingly higher compared to other departments. In order to manage the problem, we organized an education program with the participation of ED head doctor and head nurse. Unlike the previous education programs, this time we decided to perform a pre-test to measure the baseline knowledge of the sample group and a post-test to measure the effectiveness of our education. The pre- and post-tests contained the same questions about the preanalytical phase (Table I).

An education program about laboratory procedures, quality requirements in the laboratory, patient and HCW safety was planned for 36 people who were responsible for sample collection in the ED. The program was performed in three sessions to increase effectiveness as the ED stuff were shift-workers. The participants were already divided into three groups shifting for every eight hours a day. Accordingly, the same education program was repeated for each group. Hospital Quality Standards and Laboratory Quality Management Guidelines published by the Ministry of Health were used as a reference.

\section{Statistical analysis}

To evaluate the data, the SPSS 13.0 program was used. Descriptive data were evaluated by PairedSamples "t" test. The personnel's knowledge about the issue was observed by chi-square test. The level of significance was accepted as $p<0.05$. The degree of process deviation from perfection was evaluated by six sigma processes. The number of rejected per million was discovered with right proportion account over the number of accepted and rejected samples after and before the training period. Sigma level for value in the Sigma conversion table and the success rate were determined in the sigma range.

\section{Results}

In December 2014, a total of 5316 samples were received from ED and 125 of them were reject- 
Table I The questionary was composed of 11 questions on the preanalytic laboratory phase. The participants answered these questions before the education as a pre-test and after the education as a post-test.

1. Which period of laboratory process is the major source of analytical errors?
a) preanalytical
b) analytical
c) postanalytical
d) pre-preanalytical
e) post-postanalytical

2. Which anatomical region is the most preferred site for venous blood sampling?
a) dorsal hand veins
b) head veins
c) antecubital fossa veins
d) dorsal foot veins

3. Number the following tubes in order of collecting the blood samples
(...) Hemogram (purple cap)
(...) Heparinized (green cap)
(...) Blood culture
(...) Serum tubes (red, yellow and orange cap)
(...) Citrated tubes (blue and black cap)

4. What should be the right angle between the arm and the needle during blood sampling?
a) 90 degrees
b) 15-30 degrees
c) parallel to the veins
d) 120 degrees

5. Which of the following is true?
a) Only the tubes with anticoagulant should be inverted after blood sampling
b) Only the serum tubes should be inverted after blood sampling
c) All tubes should be inverted after blood sampling
d) Tubes should not be inverted after blood sampling

6. What is compromised with the rejection of samples by the laboratory?
a) Employee safety
b) Patient safety
c) Laboratory safety
d) Institution safety

7. When is the correct time for blood gas analysis following blood collection?
a) Within 5 minutes
b) Within 15 minutes
c) Within 30 minutes
d) Within 45 minutes

8. What is hemolysis?
a) The destruction or dissolution of platelets with release of cell content
b) The destruction or dissolution of macrophages with release of cell content
c) The destruction or dissolution of monocytes with release of cell content
d) The destruction or dissolution of erythrocytes with release of cell content
e) The destruction or dissolution of neutrophils with release of cell content

9. What do we call a value that represents a pathophysiological state at such variance with normal (reference values) as to be life-threatening unless something is done promptly and for which some corrective action must be taken?
a) critical (panic) value
b) high value
c) abnormal value
d) normal value

10. When is the laboratory in charge of the samples?
a) After the test requests are made. b) After the sample collection is completed

c) After the sample is accepted. d) When the samples are analyzed

11. Which region is suitable for collecting blood samples?
a) hematoma region b) presence of scar tissue on the region
c) proximally of the IV catheters
d) distally of the IV catheters 
ed; rejection rate was $2.351 \%$. The rejection rate was evaluated by the laboratory quality team and found to necessitate an education program. Most of the attendees were nurses (n: 22/55\%), with over 12 years of experience in medicine and 2 to 4 years of experience in the ER. Others were health officers and health technicians. The pre-test with questions pertaining to

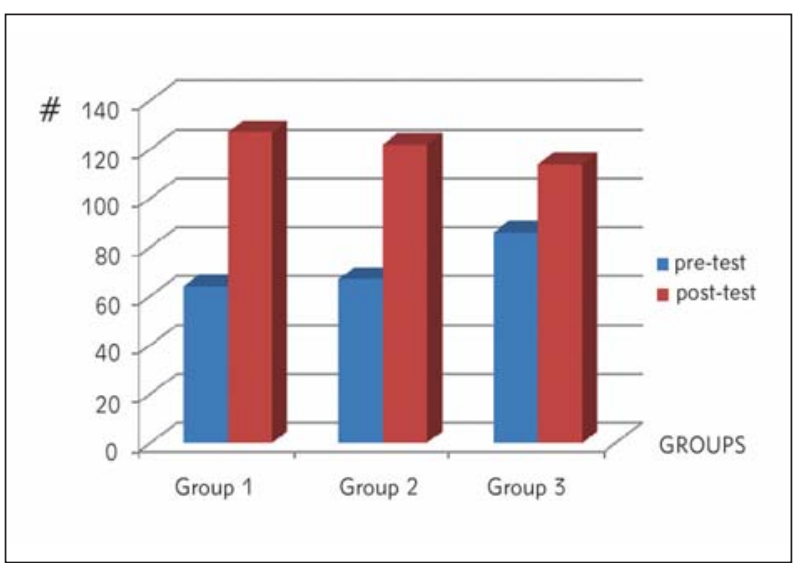

Figure 1 Comparing the post-test results with the pre-test results allowed us to observe the effect of our education program. The post-test performance of all three groups was satisfactory. The overall success in the post-test after 3 sections of training rose from $58.9 \%$ on the pre-test to $91.8 \%$

\#: total number of true results of 12 people in every group answering 11 questions $(12 \times 11=132$ as a maximum). a variety of issues about the preanalytic phase showed a success of $58.9 \%$ before training. Groups 1 and 2 showed similar performances in the pre-test while group 3 was better (Figure 1). Correct answers for particular questions were also different between groups. In the pre-test, all participants failed in answering question 3 (order of draw). More than half of participants in all groups failed in answering question 1. Groups 1 and 2 showed a failure in question 5. Questions 2 and 11 were answered correctly by all participants of group 3 (Figure 2). In the post-test, group 1 showed remarkable progress. All members of the group answered 7 of 11 questions correctly. Group 2 followed group 1 with 6 of 11 questions answered by all members. Interestingly, group 3 who had showed a better performance compared to other two groups in the pre-test, showed a worse performance in the post-test. Only 4 questions in 11 were answered correctly by all members of group 3 . Question 3 was answered correctly by all members of group 1 while 11 and 8 members of groups 2 and 3 respectively gave correct answers to the question. The overall success in the post-test was $91.8 \%$ including better performance in questions 1 and 5 (Figure 3).

Rejection rates for the following periods were observed. After the education program, in February 2015 a total sample number of 4803 was received from ED by the laboratory and 75 of them were rejected; rejection rate was $1.56 \%$ (Figure 1).

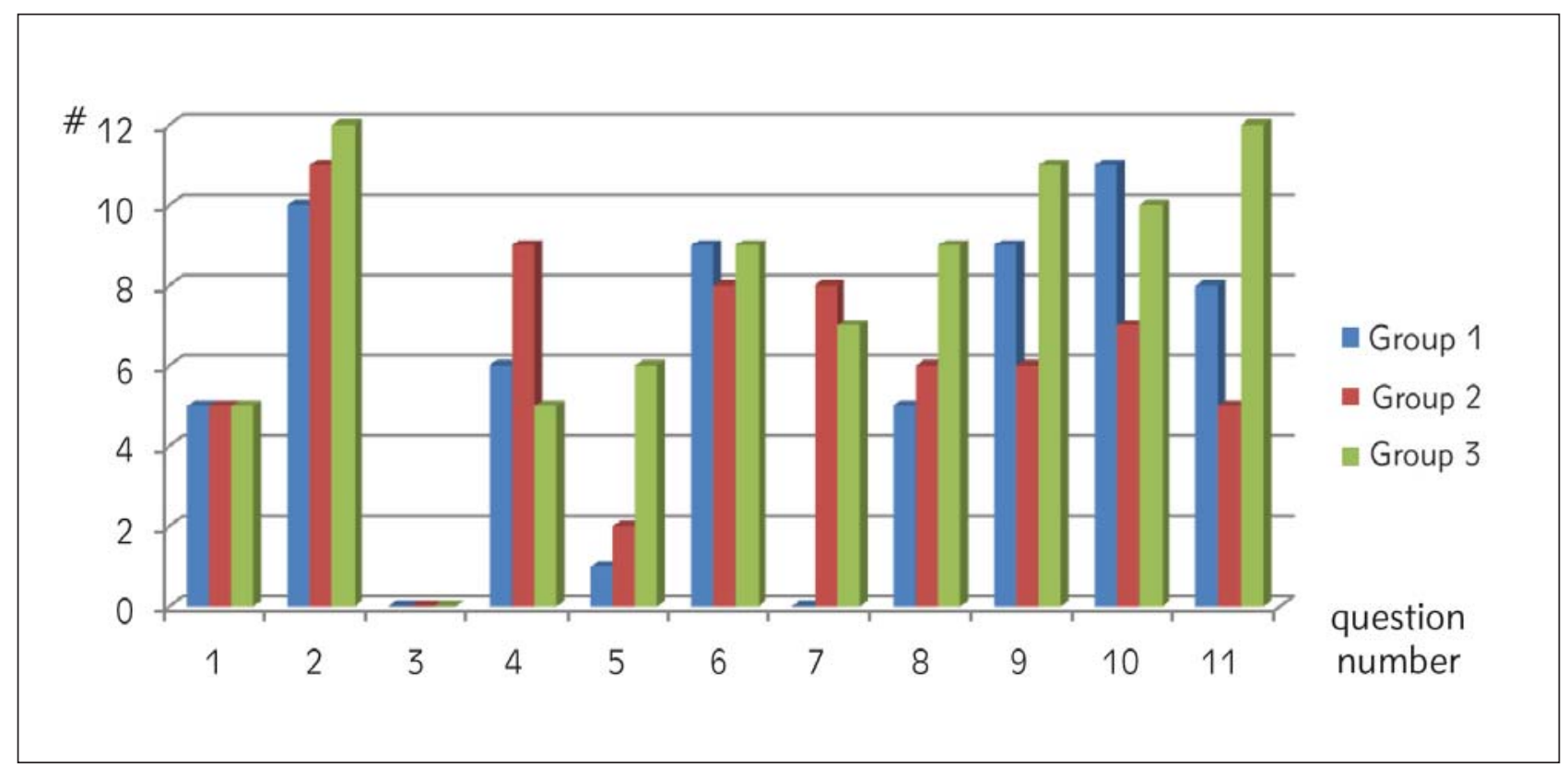

Figure 2 The pre-test performance. We used the pre-test to compare the groups and define the issues to be focused on. \#: total number of true results of 12 people in every group answering 11 questions. 


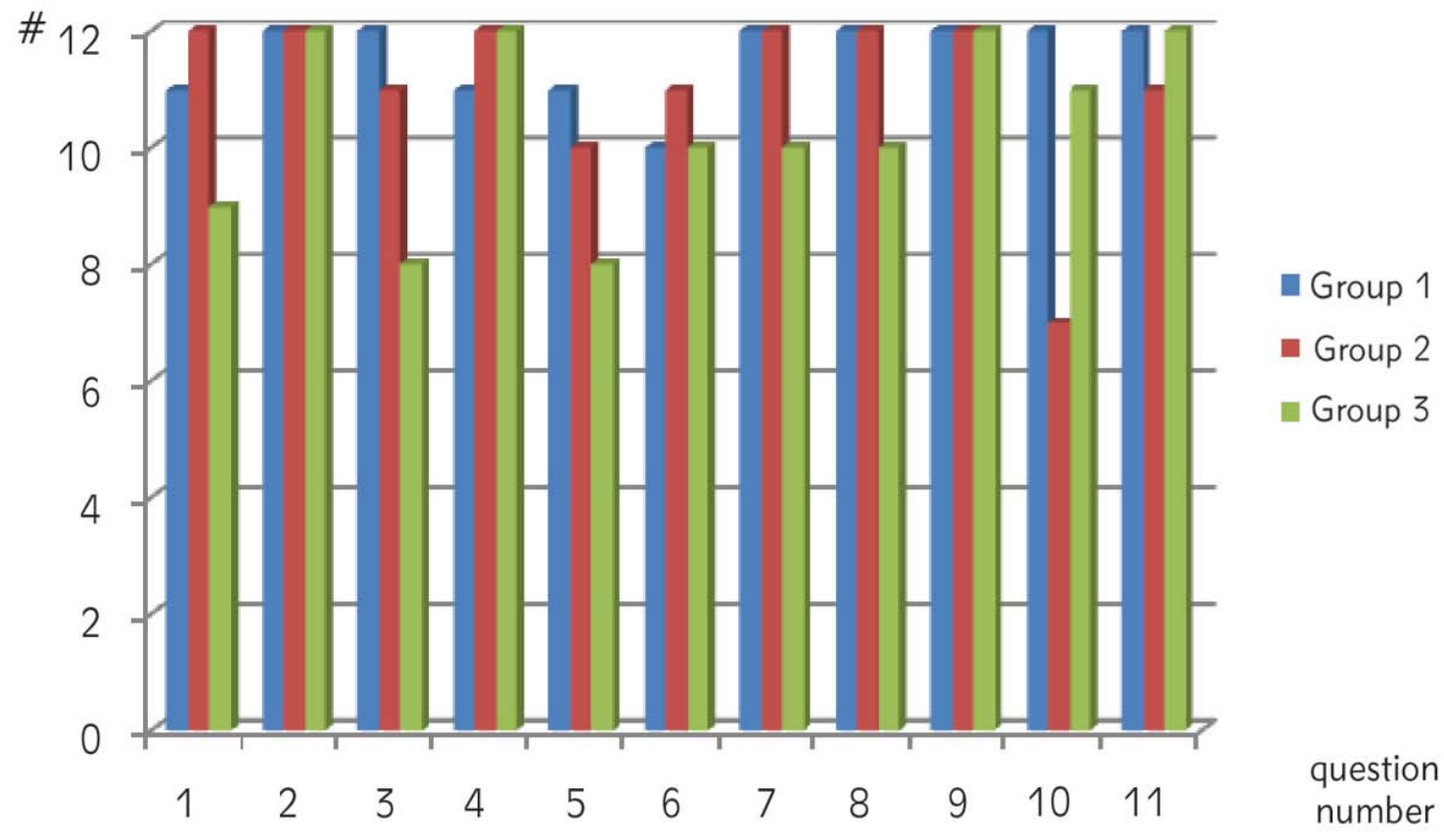

Figure 3 The post-test performance. We evaluated the post-tests as satisfactory considering the high success of all three groups.

\#: total number of true results of 12 people in every group answering 11 questions.

\section{Discussion}

Considering the entire laboratory process, it is apparent that preanalytical phase is most liable to making errors. Previous studies define the problems in the drawing and handling of biological samples. When inappropriate, preanalytic steps may lead to false test results and the safety of the patient might be compromised (1). Laboratory tests have been threatened by hemolysed and contaminated samples for quite a long time. A preanalytic problem also keeps laboratory professionals and clinicians busy and confused by inappropriate results on an inappropriate sample. Such samples lead to considerable delays in clinical decision making, prevent the setting-up of a diagnosis, or making-up one's mind on the therapy, or sadly lead to inaccurate treatment decisions $(3,5)$.

For laboratories, it is very important to implement and track the quality requirements. During out of routine times under heavy conditions, awareness of laboratory technicians also needs to be provided. Insufficient samples need to be identified well and both the laboratory workers and the clinicians need to be informed properly (2). Periodical sample rejection reports serve as a feasible application to keep aware of the preanalytic conditions. Very similar to regular testing procedures, a high rejection rate is a panic value and an indication for preventive action, as is the case in this study. ED may have more patients than other wards and high potential for panic and complications because of high-risk patients. These circumstances increase the error rates and make the ED come first in making preanalytical errors. Sample collection errors from the ED may cause a risk for patient safety and these errors have an important impact on medical treatments which depend on laboratory outcomes. Therefore, all procedures in laboratories including those in preanalytical phase need to be evaluated with total quality management $(6,7)$.

In our study, we planned an education program concerning the preanalytical phase and laboratory processes for ED staff in 3 sessions and in small groups to increase the effectiveness. Differing from our previous studies, we added a pre-test and a posttest to the education program. Both test questions were prepared to highlight the most important parts of the preanalytic phase. The pre-test was performed three days before the education presentations. Our aim was to determine the baseline awareness of the participants. The pre-test made it possible to compare the groups and define the issues to be focused on. The baseline knowledge level of our staff was lower than we had expected. The participants answered the same questions at the end of the session as a post- 
test. Correct answer rate in the post-test increased significantly compared to the pre-test. However, we waited for a fall in sample rejection rates in the next month before accepting our education program was effective.

During the education session, the pre-test was a guide: we focused on weak points and made changes in the routine flow of sessions. For example, none of the participants correctly answered the "order of draw" question. We spared extra time for this issue. We added real cases from our own hospital experience and observed a great response to these cases. Only then, some of the participants confessed that they did not believe the order of draw. Another example: we organized a live performance of blood gases analyses for group 1, as they were totally unsuccessful in that question. We also spared extra time for groups 1 and 2 as their total success was lower than group 3. Gladsome, the post-test performance of group 1 was better than the performance of group 3, so we believe our extra effort had an impact. The post-test was a measure of our performance as well as an opportunity to compare the three groups.

There are few studies on preanalytical phase problems in Turkey (6-10). The study of Kume et al. determined the most common problems as follows: the usage of syringes instead of a vacuum system for blood collection which causes insufficient fill lines, hemolysis as a result of collection by needles with small diameters, hemolysis because of blood transfer from needle to vacuum tubes without discarding the needle from the syringe and clotted samples because of insufficient mixing of anticoagulant and blood (6). Ozcan et al. (10) reported that the most common errors in preanalytical phase were contamination, clotted samples and insufficient sample volumes. They also determined that monthly trainings on preanalytical phase for phlebotomy staff in all departments and laboratory technicians and the same training program for new employees can contribute to cost savings and performance by preventing preanalytical errors in laboratory medicine.

Previously, Lippi et al. (4) designed a multicenter prospective study which was planned to compare the frequency of five most frequent preanalytical problems occurring during venous blood collection as recorded in outpatient clinics and emergency departments. According to the results of this multicenter prospective study, blood samples collected at emergency department hospitals were 10 times as faulty as those taken at outpatient clinics managed by laboratory professionals. Similarly, Berg et al. (5) observed variation in phlebotomy practice in the Majors area of their Emergency Department. Their study showed that phlebotomy techniques differ to a great extent from the standard practice. This could easily cause a much higher frequency of hemolysed samples and the wrong order of collecting potassium-EDTA-contaminated samples.

Most papers pertaining to the subject report statistical data on preanalytic error rates. After all, we are more or less aware of the sources of major problems. However, guidelines to cope with the already defined problems are still missing (11-13). Some authors go beyond, and present their education programs as a solution. Lillo et al. (14) define education as relevant in preanalytic quality improvement. Ying et al. (15) report a $50 \%$ fall in preanalytic error rates after an education program.

\section{Conclusions}

Cooperation between the ED and the laboratory is very important to reduce preanalytical errors. For this issue, all staff needs to be highly aware; they should have the required knowledge level and these need to be provided continuously. For this objective, we believe that particulary phlebotomy training at international standard levels is needed. Preanalytical errros can be prevented by taking some proper precautions and both patient safety and staff satisfaction can be provided with less effort and more financial incomes.

We here report high efficiency of an education program evidenced by a remarkable fall in sample rejection rates. The necessity to follow up the preanalytic phase closely and create communication between departments is a reality after all experiences and this study is nothing but a reiteration in that sense. Pre- and post-test applications were the goal of this study. The pre-test in particular was a very efficient guide to shape our education sessions. So efficient that three sessions with three groups were quite different in concept and duration. We do not feel confident to propose a significant positive effect but strongly recommend health care professionals a pretest prior to an education program. Future experience will show the superiority of flexible programs over solitary ones.

Ethical approval: This study was approved by Hospital Management of Antalya Education and Research Hospital (reference number: 2015/16657).

Acknowledgements: The authors would like to thank Çisem Tarhan for her contribution.

\section{Conflict of interest statement}

The authors stated that they have no conflicts of interest regarding the publication of this article. 


\section{References}

1. Simundic AM, Cornes M, Grankvist K, Lippi G, Nybo M, Kovalevskaya $S$, et al. Survey of national guidelines, education and training on phlebotomy in 28 European countries: an original report by the European Federation of Clinical Chemistry and Laboratory Medicine (EFLM) working group for the preanalytical phase (WG-PA). Clin Chem Lab Med 2013; 51: 1585-93.

2. Aykal G, Yegin A, Aydin O, Yilmaz N, Ellidag HY. The impact of educational interventions on reducing the rejection rates in the preanalytical phase. Turk J Biochem 2014; 39: 562-6.

3. Lippi G, Plebani M and Somma S, Cervellin G. Hemolyzed specimens: a major challenge for emergency departments and clinical laboratories. Crit Rev Clin Lab Sci 2011; 48: 143-53.

4. Lippi G, Caola I, Cervellin G, Milanesi B, Morandini M, Giavarina D. Error rates during blood collection in emergency departments and outpatient clinics: Results of a prospective multicenter study. Clin Chim Acta 2015; 445: 91-2.

5. Berg JE, Ahee P, Berd JD. Variation in phlebotomy techniques in emergency medicine and the incidence of haemolysed samples. Ann Clin Biochem 2011; 48: 562-5.

6. Küme T, Şişman AR and Özkaya A, Coker C. Preanalytical errors of specimens sent from the emergency department to the laboratory. Türk Klinik Biyokimya Derg 2009; 7: 49-55.

7. Lippi G, Bonelli P, Bonfanti L, Cervellin G. The use of SMonovette is effective to reduce the burden of hemolysis in a large urban emergency department. Biochem Med 2015; 25: 69-72.
8. Atay A, Demir L, Cuhadar S, Saglam G, Unal H, Aksun $S$, et al. Clinical biochemistry laboratory rejection rates due to various types of preanalytical errors. Biochem Med (Zagreb) 2014; 24: 376-82.

9. Sinici LI, Pınar A, Akbıyık F. Classification of reasons for rejection of biological specimens based on pre-preanalytical processes to identify quality indicators at a university hospital clinical laboratory in Turkey. Clin Biochem 2014; 47: 1002-5.

10. Özcan O, Güreser AS. Sources of preanalytical errors and the role of training in error prevention. Dicle Med J 2012; 39: 524-30.

11. Simundic AM, Lippi G. Preanalytical phase - a continuous challenge for laboratory professionals. Biochem Med (Zagreb) 2012; 22: 145-9.

12. Braga F, Infusino I, Panteghini M. Role and responsibilities of laboratory medicine specialists in the verification of metrological traceability of in vitro medical diagnostics. J Med Biochem 2015; 34: 282-7.

13. Lima-Oliveira G, Lippi G, Salvagno GL, Picheth G, Guidi GC. Laboratory diagnostics and quality of blood collection. J Med Biochem 2015; 34: 288-94.

14. Lillo R, Salinas M, Lopez-Garrigos M, Naranjo-Santana Y, Gutiérrez M, Marín MD, et al. Reducing preanalytical laboratory sample errors through educational and technological interventions. Clin Lab 2012; 58: 911-7.

15. Ying LH, Yang YC, Huang WF, Li YF, Song P, Chen L, Lan $Y$. Reduction of preanalytical errors in laboratory by establishment and application of training system. J Evid Based Med 2014; 7: 258-62. 